\title{
ARTYKUŁ 96 USTAWY PRAWO OCHRONY ŚRODOWISKA W ŚWIETLE KONSTYTUCYJNYCH ZASAD SUBSYDIARNOŚCI I PROPORCJONALNOŚCI
}

\section{ARTICLE 96 OF THE ACT ON ENVIRONMENTAL LAW IN VIEW OF SUBSIDIARITY AND PROPORTIONALITY PRINCIPLES}

\section{STRESZCZENIE}

Autorka porusza w swym artykule dwie podstawowe kwestie, jakie można podnieść w odniesieniu do art. 96 ustawy Prawo ochrony środowiska.. Po pierwsze: kiedy należy stosować te przepisy, co wiąże się ze zgłaszanym zarówno w piśmiennictwie, jak i orzecznictwie ich subsydiarnym charakterem. Po drugie: w jaki sposób je stosować, aby nie naruszyć zasady proporcjonalności wyrażonej w Konstytucji

" Magister prawa, doktorantka w Instytucie Nauk Prawnych Polskiej Akademii Nauk. 
Rzeczypospolitej Polskiej. Należy przy tym podkreślić, że potencjalne naruszenie zasady proporcjonalności było podstawowym zarzutem stawianym wobec art. 96 ustawy w wersji sprzed nowelizacji z dnia 10 września 2015 r. Artykuł zawiera analizę zmian dokonanych przez ustawodawcę w powyższym zakresie i próbuje znaleźć odpowiedź na pytanie, czy usunięte zostały w ten sposób wątpliwości co do roli, jaką pełnią $\mathrm{w}$ systemie ochrony powietrza środki prawne podejmowane na podstawie art. 96 ustawy.

\section{Słowa kluczowe}

Ochrona powietrza; sejmik; proporcjonalność; subsydiarność.

\section{ABSTRACT}

The author deals with two basic questions which can be posed in relation to article 96 of the Polish Act on Environmental Law. Firstly: when should article 96 apply - which is connected with its subsidiary character - and secondly: how should it apply in accordance with the proportionality principle expressed in the Polish Constitution. It must be underlined that the potential infringement of this principle led to the amendment of article 96 voted on 10 September 2015. The author analyses amendments introduced by the Parliament in this scope and whether all doubts concerning the position of article 96 in the Polish system of air protection were resolved.

\section{Keywords}

Protection of air quality; sejmik; proportionality; subsidiarity.

\section{WSTĘP}

W ostatnim czasie wiele jednostek samorządu terytorialnego podejmuje działania prawne zmierzajace do poprawy jakości powietrza. Najbardziej znanym przykładem jest Kraków, dla którego obszaru Sejmik Województwa Małopolskiego sięgnął po niestosowany wcześniej w praktyce organów samorzą3/2016 dowych art. 96 ustawy z dnia 27 kwietnia 2001 r. Prawo ochro- 
ny środowiska ${ }^{1}$, korzystając $\mathrm{z}$ przewidzianej $\mathrm{w}$ tym przepisie kompetencji do przyjęcia uchwały mającej na celu zapobieżenie negatywnemu oddziaływaniu na środowisko lub zabytki. Nie odniosło to zamierzonego skutku, gdyż Wojewódzki Sąd Administracyjny w Krakowie ${ }^{2}$ w dniu 22 sierpnia 2014 r. stwierdził nieważność uchwały sejmiku z dnia 25 listopada 2013 r. ${ }^{3}$, zaś skargi kasacyjne na to orzeczenie, wniesione zarówno przez samorząd województwa małopolskiego, jak i organizacje pozarządowe, Naczelny Sąd Administracyjny oddalił w dniu 25 września $2015 \mathrm{r}^{4}$. Jeszcze w trakcie instancyjnego toku postępowania sądowoadministracyjnego, w dniu 10 września 2015 r. Sejm uchwalił nowelizację art. 96 u.p.o.ś. ${ }^{5}$, która miała na celu „wyeliminowanie wątpliwości prawnych związanych z zakresem uchwały i sposobem jej realizacji"6. Na podstawie znowelizowanego art. 96 u.p.o.ś. Sejmik Województwa Małopolskiego przyjął w dniu 25 listopada 2015 r. kolejną uchwałę7. Również i tym razem, po wniesieniu skarg przez osoby fizyczne, postanowienia uchwały Sejmiku staną się przedmiotem kontroli sądowoadministracyjnej.

Wydaje się, że w odniesieniu do art. 96 u.p.o.ś. należy zastanowić się nad dwiema podstawowymi kwestiami: kiedy należy sięgać po zastosowanie tych przepisów i w jaki sposób je sto-

1 Tekst jedn. Dz. U. z 2016 r., poz. 672 ze zm., dalej cyt. u.p.o.ś.

2 Sygn. akt II SA /Kr 490/14.

3 Uchwała nr XLIV/703/13 Sejmiku Województwa Małopolskiego z dnia 25 listopada 2013 r. w sprawie określenia rodzajów paliw dopuszczonych do stosowania na obszarze Gminy Miejskiej Kraków, http://bip.malopolska.pl/ umwm/Article/get/id,833236.html.

4 Sygn. akt II OSK 255/15. $2015 \mathrm{r}$.

5 Dz. U. z 2015 roku, poz. 1593. Zmiana weszła w życie 12 listopada

6 Z uzasadnienia prawnego do projektu ustawy, druk nr 3667, Warszawa 20 lutego 2015 r., http://orka.sejm.gov.pl/Druki7ka.nsf/0/285B19E89CEFD4CEC1257E83002582EC/\%24File/3667.pdf.

7 Uchwała Nr XVIII/243/16 Sejmiku Województwa Małopolskiego z dnia 15 stycznia 2016 r. w sprawie wprowadzenia na obszarze Gminy Miejskiej Kraków ograniczeń w zakresie eksploatacji instalacji, w których następuje spalanie paliw. 
sować, aby nie naruszyć Konstytucji Rzeczypospolitej Polskiej, ustaw, a także prawa unijnego.

Odpowiedź na pierwsze pytanie wiąże się ze zgłaszanym zarówno w piśmiennictwie, jak i orzecznictwie ${ }^{9}$ subsydiarnym sposobem ich stosowania. Jednakże w praktyce istnieją wątpliwości co do tego, czy art. 96 u.p.o.ś. rzeczywiście jest traktowany jako instrument o charakterze uzupełniającym w odniesieniu do pozostałych elementów prawnego systemu ochrony powietrza.

Natomiast konstytucyjna zasada proporcjonalności wyznacza sposób stosowania art. 96 u.p.o.ś.. Podstawowym zarzutem zgłaszanym ${ }^{10} \mathrm{w}$ odniesieniu do art. 96 u.p.o.ś. w dawnym brzmieniu było potencjalne naruszenie zasady proporcjonalności wyrażonej w art. 31 ust. 3 Konstytucji RP. Niewątpliwie bowiem przyznanie sejmikowi zbyt ogólnie sformułowanych kompetencji stanowiło ingerencję $\mathrm{w}$ sferę praw i wolności jednostki, w tym w swobodę prowadzenia działalności gospodarczej. Pożądanym zatem działaniem ustawodawcy było wprowadzenie ograniczeń, np. czasowych i merytorycznych, dla stosowania nakazów wprowadzanych uchwałą sejmiku, jak również co do określenia sposobu realizacji, rodzaju i zakresu kontroli tych obowiązków.

8 Konstytucja Rzeczypospolitej Polskiej z dnia 2 kwietnia 1997 r., Dz. U. Nr 78, poz. 483 ze zm.

9 Np. O. Możdżyń, Lepsza jakość powietrza i ochrona przed hałasem - planowane zmiany $w$ art. 96 Prawa ochrony środowiska, „Prawo i Środowisko” 2015, nr 2, s. 80 oraz z uzasadnienia do wyroku Wojewódzkiego Sądu Administracyjnego w Krakowie, sygn. akt II SA / Kr 490/14: „literalna interpretacja art. 96 u.p.o.ś. wymusza zaś stosowanie przewidzianych w nim możliwości tylko w sytuacjach wyjątkowych i na zasadach równego traktowania podmiotów korzystających ze środowiska w sytuacji ustalonej już uprzednio w granicach dotychczasowego porządku prawnego, nie zaś jako instrumentu osiągania doraźnych efektów, nawet w imię ważnych społecznie celów [...]".

10 Por. np. B. Rakoczy, w: Z. Bukowski, E.K. Czech, K. Karpus, B. Rakoczy, Prawo ochrony środowiska. Komentarz, Warszawa 2013, s. 156 (powoływany dalej jako Rakoczy B., Komentarz), oraz M. Pchałek, w: M. Górski, M. Pchałek, W. Radecki, J. Jerzmański, M. Bar, S. Urban, J. Jendrośka, Prawo ochrony środowiska. Komentar\%, Warszawa 2014, s. 374. 
Celem niniejszego artykułu jest zbadanie, czy nowelizacja u.p.o.ś. dokonana w zakresie jej art. 96 wyeliminowała wcześniejsze wątpliwości interpretacyjne, czy też, wręcz przeciwnie, jeszcze je pogłębiła.

\section{ARTYKUŁ 96 U.P.O.Ś. A ZASADA SUBSYDIARNOŚCI}

Pojęcie subsydiarności wiąże się z pojęciem decentralizacji i odnosi się do działania organów państwa i podziału kompetencji między jednostki centralne i lokalne. Podstawową funkcją zasady subsydiarności wyrażoną $\mathrm{w}$ preambule Konstytucji RP jest „umacnianie uprawnień obywateli i wspólnot”. Praktyczne zastosowanie zasady subsydiarności władzy publicznej w stosunkach wewnętrznych zamyka się w formule: „oddać co można i powstrzymać się od ingerencji"11. Zgodność danego działania administracji publicznej z zasadą subsydiarności można badać na dwóch płaszczyznach: po pierwsze, czy dana materia powinna w ogóle wchodzić w sferę imperium - władczych kompetencji administracji jako zadanie reglamentacyjno-porządkowe, oraz, po drugie, na jakim najniższym możliwym szczeblu władz publicznych powinno zostać wykonane dane zadanie publiczne ${ }^{12}$. Dopiero jeśli danemu zadaniu nie może podołać gmina, która cieszy się domniemaniem kompetencji w zakresie zadań lokalnych, wówczas dopiero powinien być zaangażowany samorząd powiatu lub województwa samorządowego. Władza państwowa może zaś działać dopiero wówczas, gdy nie można oczekiwać skutecznej interwencji organów samorządu terytorialnego najwyższego szczebla ${ }^{13}$.

11 A. Szpor, Państwo a subsydiarność jako zasada prawa w UE $i$ w Polsce, „Samorząd Terytorialny” 2001, nr 1-2, s. 19.

12 O pojęciu „zadania” w doktrynie prawa administracyjnego por. A. Barczak, Zadania samorzadu terytorialnego $w$ zakresie ochrony środowiska, Warszawa 2006, str. 18-19.

13 H. Izdebski, Samorząd terytorialny. Podstawy ustroju i działalności, Warszawa 2014, s. 150. 
W kontekście art. 96 u.p.o.ś. oznacza to, że organy samorządu województwa, podejmujące działania legislacyjne na podstawie tego przepisu ustawy, powinny najpierw dokonać analizy, czy zadanie publiczne tam określone $\mathrm{w}$ postaci „zapobieżenia negatywnemu oddziaływaniu na zdrowie ludzi lub na środowisko" wymaga interwencji sejmiku, czy też może być pomyślnie wykonywane na szczeblu gminy lub powiatu. Na marginesie można zauważyć, że w praktyce takie działania są podejmowane w celu zapobieżenia dalszemu negatywnemu oddziaływaniu na zdrowie ludzi lub na środowisko, gdyż organy sięgają po ten instrument dopiero w sytuacji przekroczenia poziomów dopuszczalnych szkodliwych substancji w powietrzu a więc, gdy wcześniej podjęte działania (o ile były podejmowane) okazały się nieskuteczne. Niemniej omawiana nowelizacja przepisów niewiele $\mathrm{w}$ tym zakresie zmieniła.

Zasada subsydiarności obowiązuje również w relacjach Unia Europejska - państwa członkowskie, co w dziedzinie ochrony środowiska przekłada się na konkurencyjny podział kompetencji legislacyjnych i doktrynę „zajętego pola”. Oznacza to, że prawo miejscowe tworzone na podstawie art. 96 u.p.o.ś. nie może wkraczać $\mathrm{w}$ tę samą materię, którą dyrektywa unijna reguluje w odmienny sposób. Takie stanowisko zajął również NSA $^{14}$ w przywołanym już wyroku dotyczącym uchwały Sejmiku Województwa Małopolskiego: „w żadnym przypadku przepisy prawa miejscowego nie mogą służyć implementacji do prawa polskiego dyrektywy z prawa unijnego, ponieważ $\mathrm{w}$ prawie polskim następuje to w formie ustawy". Dotyczy to więc także dyrektywy w sprawie jakości powietrza i czystszego powietrza dla Europy ${ }^{15}$ oraz dyrektywy w sprawie arsenu, kadmu, rtęci, niklu i wielopierścieniowych węglowodorów aromatycznych w otaczającym powietrzu ${ }^{16}$. Zresztą art. 96 pojawił się już w tek-

14 Sygn. akt II OSK 255/15.

15 Dyrektywa Parlamentu Europejskiego i Rady 2008/50/WE z dnia 21 maja 2008 r. w sprawie jakości powietrza i czystszego powietrza dla Europy (Dz. Urz. UE L 152 z 11.6.2008, s. 1), dalej cyt.: dyrektywa CAFE.

16 Dyrektywa 2004/107/WE Parlamentu Europejskiego i Rady z 15 grudnia 2004 r. w sprawie arsenu, kadmu, rtęci, niklu i wielopierścieniowych 
ście pierwotnym ustawy z $2001 \mathrm{r} .{ }^{17}$, a zatem przed wstąpieniem Polski do Unii Europejskiej i trudno w tym przypadku mówić o transpozycji przepisów unijnych.

Wracając do kwestii subsydiarnego charakteru aktu prawnego stanowionego na podstawie art. 96 u.p.o.ś., należy zwrócić uwagę na pewien paradoks. Mianowicie sam fakt, że mamy do czynienia z aktem prawa miejscowego, sytuuje go niżej w hierarchii aktów prawnych powszechnie obowiązujących. Działania legislacyjne podejmowane przez samorząd terytorialny powinny mieć niejako ze swej natury charakter uzupełniający, dostosowujący krajowe normy prawne do warunków lokalnych. Tu jednak należy zwrócić uwagę, że jeśli chodzi o działania zmierzające do przywrócenia naruszonych wymagań jakości powietrza, dochodzi do swoistego odwrócenia tej sytuacji, gdyż w pierwszej kolejności opierają się one właśnie na systemie aktów prawa miejscowego. Taki bowiem status mają programy ochrony powietrza podejmowane na podstawie art. $84 \mathrm{w}$ związku z art. 91 ust. 3 u.p.o.ś., które są uznawane za podstawowe akty prawne o charakterze wiążącym, dotyczące przywracania standardów jakości powietrza. Ważnym instrumentem, choć nie bezpośrednio, mogą być również miejscowe plany zagospodarowania przestrzennego.

Podjęcie tego typu działań na szczeblu krajowym jest fakultatywne i może, na podstawie art. 91c u.p.o.ś., nastąpić dopiero wtedy, gdy przekroczenie poziomów dopuszczalnych lub docelowych występuje na „znacznym obszaru kraju”, a „środki podjęte przez organy samorządu terytorialnego nie wpływają na ograniczenie emisji zanieczyszczeń do powietrza". Krajowy program ochrony powietrza, opracowywany w takim przypadku przez ministra właściwego do spraw środowiska, wyznacza cele i kierunki działań, jakie powinny być uwzględniane w progra-

węglowodorów aromatycznych w otaczającym powietrzu, Dz. Urz. UE L 23 z 26.1.2005, s. 3.

17 Tekst pierwotny ustawy (Dz. U. z 2001 Nr 62, poz. 627) w brzmieniu: „Wojewoda może, w drodze rozporządzenia, w celu zapobieżenia negatywnemu oddziaływaniu na środowisko lub na dobra kultury określić dla terenu województwa bądź jego części rodzaje lub jakość paliw dopuszczonych do stosowania, a także sposób realizacji i kontroli tego obowiązku". 
mach ochrony powietrza, jednak ustawodawca nie określa, jaki charakter prawny ma taki krajowy program. Można domniemywać, że nie jest to w szczególności rozporządzenie, gdyż program ogłaszany jest nie w Dzienniku Ustaw, ale w Dzienniku Urzędowym Rzeczypospolitej Polskiej „Monitor Polski”. Zatem możliwość wpływania na treść aktów prawa miejscowego przez dokument o charakterze czysto planistycznym, czy też - jak to określa ustawa - „strategicznym”, budzi uzasadnione wątpliwości z punktu widzenia katalogu źródeł prawa powszechnie obowiązującego $^{18}$. Można go traktować jako odpowiednik unijnego „soft law”, który stanowi przykład zinstrumentalizowanego planowania i koordynacji działań w danej dziedzinie, w tym przypadku w zakresie ochrony jakości powietrza.

Na podstawie art. 91c u.p.o.ś. trudno wysnuć jakiekolwiek potencjalne związki krajowego programu ochrony powietrza $\mathrm{z}$ regulacjami przyjmowanymi na podstawie art. 96, jednak w praktyce takowe się pojawiają. Krajowy program ochrony powietrza do 2020 r. (z perspektywą do 2030 r.), obowiązujący od 1 października 2015 r. ${ }^{19}$, stanowi, iż w ramach stworzenia ram prawnych sprzyjających realizacji efektywnych działań mających na celu poprawę jakości powietrza, priorytetem jest „wprowadzenie zmian prawnych w zakresie art. 96 (stworzenie możliwości wprowadzenia ograniczeń w zakresie jakości paliw stosowanych na danym obszarze)", co - jak wiadomo zostało już zrealizowane. Fakt umieszczenia tego typu komunikatu w dokumencie strategicznym na szczeblu ogólnopolskim potwierdza tezę, że w praktyce organy administracji rządowej przypisują przepisowi art. 96 u.p.o.ś. rolę istotną, jeśli nie wręcz pierwszoplanową $\mathrm{W}$ walce $\mathrm{z}$ zanieczyszczeniem powietrza, mimo iż nie ma ku temu podstaw systemowych.

Kolejnym nieporozumieniem jest, jak się wydaje, uczynienie z uchwał podejmowanych na podstawie art. 96 u.p.o.ś.

18 B. Rakoczy, Komentarz, s. 140.

19 Krajowy program ochrony powietrza do 2020 roku (z perspektywą do 2030 roku), obowiązujący od 1 października 2015 roku, s. 7, s. 51, https://www.mos.gov.pl/g2/big/2015_09/e1dcdab8f1749936fd2ef53aefc3a7ba.pdf 
instrumentów do walki z tzw. smogiem ${ }^{20}$. Smog jest nadzwyczajnym zjawiskiem, które nasila się w określonych warunkach i trwa przez ograniczony czas. M. Górski stwierdza, że dla tzw. sytuacji smogowych powinny zostać stworzone szczególne wymagania jakości powietrza, stanowiące uzupełnienie systemu głównych standardów i parametrów ${ }^{21}$. Parametry jakości mające $\mathrm{w}$ takich sytuacjach zastosowanie to poziomy informowania i poziomy alarmowe.

Artykuł 32 ustawy z dnia 31 stycznia 1980 r. o ochronie i kształtowaniu środowiska ${ }^{22}$ wprost zezwalał, by w razie szczególnie niekorzystnych warunków lub z innych przyczyn, mogących spowodować przekroczenie dopuszczalnego stężenia zanieczyszczeń powietrza na danym terenie, w stopniu stanowiącym bezpośrednie zagrożenie dla życia lub zdrowia ludzi, zarządzić na czas oznaczony ograniczenie lub zakaz wprowadzania określonych zanieczyszczeń do powietrza.

Natomiast w art. 96 u.p.o.ś., którego cel jest sformułowany ogólnie jako zapobieganie negatywnemu oddziaływaniu na zdrowie ludzi lub na środowisko eksploatacji instalacji, w których następuje spalanie paliw, próżno szukać podobnych odniesień do sytuacji „nadzwyczajnego”, „szczególnie niekorzystnego" zanieczyszczenia powietrza, brak również powiązania wprowadzenia zakazów lub ograniczeń z przekroczeniem poziomów informowania czy alarmowych. Wykładnia literalna w żadnym wypadku nie prowadzi do wniosku, by przepis ten był w sposób szczególny przewidziany do zwalczania tzw. sytuacji smogowych. Może na to jedynie pośrednio, funkcjonalnie wskazywać nowy element wprowadzony nowelizacją, mianowicie możliwość określenia przez sejmik okresu obowiązywania ograniczeń lub zakazów w ciągu roku - co wskazywałoby na „sezonowość” zwalczanego zjawiska.

20 W publicystyce zyskały one miano tzw. „uchwał antysmogowych”.

21 M. Górski, w: M. Górski, M. Pchałek, W. Radecki, J. Jerzmański, M. Bar, S. Urban, J. Jendrośka, Prawo ochrony środowiska. Komentarz, Warszawa 2014, s. 236.

22 Tekst jedn. Dz. U. z 1994 r., nr 49, poz. 196. 
W doktrynie za instrumenty stricte ,antysmogowe"23 uznawane są plany działań krótkoterminowych, których tworzenie zostało unormowane w art. 92 u.p.o.ś. Plany te przyjmowane są $\mathrm{w}$ formie uchwały sejmiku województwa właśnie $\mathrm{w}$ przypadku ryzyka przekroczenia poziomów alarmowych, dopuszczalnych lub docelowych substancji w powietrzu. Powinny one określać działania, które zmniejszą ryzyko wystąpienia takich przekroczeń oraz ograniczyć skutki i czas ich trwania, jeśli już zaistniały. $\mathrm{Na}$ ich podstawie należy określić listę podmiotów korzystających ze środowiska, obowiązanych do ograniczenia lub zaprzestania wprowadzania z instalacji gazów lub pyłów do powietrza, sposób organizacji i ograniczeń lub zakazu ruchu pojazdów i innych urządzeń napędzanych silnikami spalinowymi. Nakaz powiadomienia społeczeństwa i innych podmiotów o zaistniałym ryzyku i ich obowiązkach przewidziany jest w art. 93 u.p.o.ś.

Jednak problemem, który dotyka planów działań krótkoterminowych, a w konsekwencji osłabia możliwość jego praktycznego zastosowania, są wątpliwości dotyczące ich prawnie wiążącego charakteru ${ }^{24}$, gdyż brak w ustawie stwierdzenia wprost, iż są to akty prawa miejscowego. Dotyczy to zwłaszcza planów, które tworzone być mają w przypadku pojawienia się ryzyka przekroczenia poziomu docelowego substancji w powietrzu. Plan taki, w przeciwieństwie do planu przyjmowanego na wypadek ryzyka przekroczenia poziomu dopuszczalnego, nie stanowi części uchwały w przedmiocie programu ochrony powietrza ${ }^{25}$. Jednak w doktrynie i orzecznictwie przyjmuje się, że - jeśli ustawa nie określa wprost, że dany akt lokalnego legislatora jest lub nie jest aktem prawa miejscowego - to konieczne jest ustalenie jego przymiotu prawotwórczego w drodze

23 A. Lipiński, Prawne podstawy ochrony środowiska, Warszawa 2007, s. 234.

24 M. Górski, Nowe regulacje prawne w zakresie ochrony jakości powietrza monitoring i przywracanie wymaganego stanu jakości powietrza, „Acta Iuris Stetinensis 5. Zeszyty Naukowe Uniwersytetu Szczecińskiego” 2014, nr 823, s. 244.

25 A. Dubowska, Plan działań krótkoterminowych jako prawny instrument ochrony powietrza, „Przegląd Prawa Ochrony Środowiska” 2015, nr 2, s. 105. 
analizy jego cech materialnych i formalnych. W obliczu faktu, iż częścią składową planów są normy o charakterze generalnym i abstrakcyjnym, nakładające obowiązki na podmioty korzystające środowiska, odmówienie im przymiotu normatywności kłóciłoby się z założeniem racjonalnego ustawodawcy. Wątpliwości wynikają niestety z często spotykanej w treści ustawy niedbałości i braku konsekwencji ustawodawcy, które utrudniają stosowanie i egzekwowanie tych przepisów.

Dlatego zarówno przed, jak i po nowelizacji językowa wykładnia art. 96 u.p.o.ś. prowadzi do wniosku, iż regulacja ta służy ogólnej ochronie powietrza. Konsekwencją takiej tezy jest $\mathrm{w}$ istocie potwierdzenie subsydiarnego charakteru art. 96, gdyż podstawowym instrumentem ogólnej ochrony powietrza jest $\mathrm{w}$ polskim systemie prawnym program ochrony powietrza uchwalany, w drodze aktu prawa miejscowego, przez sejmik województwa na podstawie art. 84 ust. 1, w związku z art. 91 ust. 3 u.p.o.ś. Oznacza to, że działania podejmowane na podstawie art. 96 u.p.o.ś. powinny mieć charakter posiłkowy.

\section{ARTYKUŁ 96 U.P.O.Ś. A ZASADA PROPORCJONALNOŚCI}

Zagadnienie proporcjonalności rozwiązań przyjętych w art. 96 u.p.o.ś. można rozpatrywać na dwóch płaszczyznach, gdyż z jednej strony należy badać zgodność samego upoważnienia ustawowego z zasadą proporcjonalności, a z drugiej jej konkretyzację w postaci aktów prawa miejscowego stanowionych na tej podstawie.

Odnośnie wymogów formułowanych wobec upoważnienia ustawowego H. Izdebski ${ }^{26}$ zwraca uwagę, iż musi ono „w sposób precyzyjny określać zakres spraw przekazanych do unormowania, przy czym powinny być to materie tożsame $\mathrm{z}$ tymi uregulowanymi w ustawie udzielającej upoważnienia do ustanowienia danego aktu", czyli spełniać zasady tzw. rzetelnej legislacji,

${ }^{26}$ H. Izdebski, Samorzq̨d terytorialny, s. 415. 
a wśród nich na plan pierwszy wybija się zasada określoności przepisów prawnych ${ }^{27}$. W ocenie Trybunału Konstytucyjnego ${ }^{28}$ upoważnienie ustawowe powinno spełniać „nakaz kompletności ograniczenia danego prawa i wolności, tak aby już na podstawie lektury przepisów ustawy można było wyznaczyć kompletny zarys (kontur) tego ograniczenia. Niedopuszczalne jest natomiast przyjmowanie w ustawie uregulowań blankietowych, pozostawiających organom władzy wykonawczej czy organom samorządu terytorialnego swobodę normowania ostatecznego kształtu owych ograniczeń, a w szczególności wyznaczania zakresu tych ograniczeń".

Jak okazało się w praktyce, ogólnie sformułowany art. 96 u.p.o.ś. w brzmieniu przed nowelizacją stwarzał duże problemy interpretacyjne, w tym dla organów samorządowych. Przekroczenie granic upoważnienia ustawowego było jednym z zarzutów podniesionych wobec uchwały Sejmiku Małopolskiego, który w pełni został uwzględniony zarówno przez WSA, jak i NSA. Nowelizacja u.p.o.ś. w zakresie art. 96 miała na celu właśnie doprecyzowanie zakresu uchwał podejmowanych na jej podstawie. Pozytywnie należy więc ocenić zwłaszcza wprowadzenie wymogu w postaci określenia rodzajów podmiotów lub instalacji, dla których wprowadza się ograniczenia lub zakazy w zakresie eksploatacji instalacji, w których następuje spalanie paliw.

Wracając do zagadnienia proporcjonalności aktu prawnego rozpatrywanego in abstracto, podważany przepis prawny należy poddać tzw. trójstopniowemu testowi proporcjonalności, który polega na ocenie ingerencji normatywnej z następujących puktów widzenia: 1) czy jest ona w stanie doprowadzić

27 Wyrok TK z dnia 30.10.2001 r., sygn. akt K 33/00: „po pierwsze - każdy przepis ograniczający konstytucyjne wolności lub prawa winien być sformułowany w sposób pozwalający jednoznacznie ustalić, kto i w jakiej sytuacji podlega ograniczeniom (kryterium podmiotowe). Po drugie - przepis taki powinien być na tyle precyzyjny, aby zapewniona była jego jednolita wykładnia i stosowanie (kryterium przedmiotowe). Po trzecie - przepis taki winien być tak ujęty, aby zakres jego zastosowania obejmował tylko te sytuacje, w których działający racjonalnie ustawodawca istotnie zamierzał wprowadzić regulację ograniczającą korzystanie z konstytucyjnych wolności i praw".

28 Wyrok TK z dnia 12.01.2000 r., sygn. akt P 11/08. 
do zamierzonych przez ustawodawcę skutków (kryterium przydatności normy), 2) czy jest ona niezbędna (konieczna) dla ochrony interesu publicznego, z którym jest powiązana (kryterium konieczności), 3) czy jej efekty pozostają w proporcji do nałożonych przez nią na obywatela ciężarów lub ograniczeń (kryterium proporcjonalności sensu stricto), przy czym „owa niezbędność oznacza również nakaz stosowania środków jak najmniej uciążliwych dla podmiotów, których prawa lub wolności ulegną ograniczeniu, bo ingerencja w sferę statusu jednostki musi pozostawać w racjonalnej i odpowiedniej proporcji do celów, których ochrona uzasadnia dokonane ograniczenie"29. Im bardziej drastyczne jest wkroczenie w materię konstytucyjnie chronionych praw podstawowych, tym bardziej rygorystycznym przesłankom powinna podlegać regulacja ustawowa ${ }^{30}$.

Zasada proporcjonalności wyrażona w art. 31 ust. 3 Konstytucji RP stanowi, iż ograniczenia $\mathrm{w}$ zakresie korzystania z konstytucyjnych wolności i praw mogą być ustanawiane tylko w akcie o randze ustawy, jednak nie wyklucza to, aby - jak to określa K. Wojtyczek ${ }^{31}$ - „ustawodawca określając w ustawie pewne podstawowe elementy ograniczeń, ich konkretyzację i uzupełnienie powierzył innym organom państwa, np. jednostkom samorządu terytorialnego", tym bardziej, że akurat względy ochrony środowiska i życia ludzkiego należą do przesłanek uzasadniających ingerencję w sferę wolności i praw konstytucyjnych jednostki. B. Rakoczy ${ }^{32}$ zauważa, że ponieważ „zakazy umieszczone $\mathrm{w}$ prawie miejscowym mogą odnosić się do praw i wolności konstytucyjnych, organ stanowiący powinien uwzględniać przesłanki zasady proporcjonalności”. Zatem nie-

29 Wyrok TK z dnia 15.7.2009 (K 64/07).

30 L. Bosek, M. Wild, Kontrola konstytucyjności prawa. Zagadnienia ustrojowe, procesowe i materialnoprawne, Warszawa 2011, s. 271 oraz przywołane tamże wyroki TK: z dnia 23.6.2009 r. (K 54/07), 12.1.1999 r. (P 2/98), 22.9.2005 r. (Kp 1/05), 12.12.2005 (K 32/04), 18.1.2006 r. (K 21/05), 13.3.2007 (K 8/07).

31 K. Wojtyczek, Granice ingerencji ustawodawczej $w$ sfere praw człowieka $w$ Konstytucji RP, Kraków 1999, s. 10.

32 B. Rakoczy, Ograniczenie praw i wolności jednostki ze względu na ochronę środowiska w Konstytucji Rzeczypospolitej Polskiej, Toruń 2006, s. 175. 
wątpliwie uchwały sejmiku w przedmiocie wprowadzenia zakazów lub ograniczenia w zakresie eksploatacji instalacji, w których następuje spalanie paliw, co potencjalnie godzi $\mathrm{w}$ takie prawa i wolności jednostki, jak swoboda prowadzenia działalności gospodarczej czy prawo własności, powinny być przedmiotem analizy z punktu widzenia zgodności z zasadą proporcjonalności.

Odnośnie przesłanki konieczności w przypadkach ograniczania praw i wolności ze względu na ochronę środowiska B. Rakoczy zauważa, że „zakaz lub ograniczenie może być wprowadzone jedynie wtedy, gdy jest to konieczne i ponadto nie ma innego sposobu ochrony środowiska, jak poprzez wprowadzenie tych zakazów"33, przy czym okoliczność, iż nie ma innej możliwości ochrony środowiska, powinna zostać ustalona w sposób obiektywny. Ponadto Autor ten stwierdza, że „dopiero analiza konkretnej sytuacji faktycznej i jurydycznej pozwoli określić, czy została naruszona istota prawa lub wolności" ${ }^{34}$.

Przechodząc zatem do rozważań in concreto, na podstawie znowelizowanego art. 96 u.p.o.ś. w dniu 15 stycznia 2016 r. została przyjęta uchwała Sejmiku Województwa Małopolskiego, która dla obszaru administracyjnego Gminy Miejskiej Kraków określiła rodzaje paliw dopuszczonych do stosowania $\mathrm{w}$ instalacjach, w których następuje spalanie paliw w rozumieniu art. 3 pkt 3 ustawy z dnia 10 kwietnia 1997 r. Prawo energetyczne ${ }^{35}$. Zgodnie z § 4 uchwały dopuszczone do stosowania zostały gaz ziemny wysokometanowy lub zaazotowany (w tym skroplony gaz ziemny), propan-butan, biogaz rolniczy lub inne rodzaje gazu palnego oraz lekki olej opałowy w rozumieniu art. 2 ust. 1 pkt 8 ustawy z dnia 25 sierpnia 2006 r. o systemie monitorowania i kontrolowania jakości paliw ${ }^{36}$. A contrario, oznacza to, że stosowanie innych rodzajów paliw, w tym paliw stałych, np. węgla kamiennego, zostało zakazane. Uchwała ma wejść w życie z dniem 1 września 2019 r.

33 B. Rakoczy, Ograniczenie praw i wolności, s. 176.

34 Ibidem s. 131.

35 Tekst jedn. Dz. U. z 2012 r., poz. 1059 ze zm.

36 Tekst jedn. Dz. U. z 2016 r., poz. 1928 ze zm. 
W kontekście spełnienia testu proporcjonalności aktu prawnego, a zwłaszcza kryterium konieczności, powstaje pytanie, czy sejmik przed podjęciem uchwały o bezwględnym zakazie stosowania danego rodzaju paliwa nie powinien był w pierwszej kolejności skorzystać z mniej kategorycznych ograniczeń praw i wolności jednostki. Tym bardziej, że możliwości takie stwarza właśnie znowelizowana ustawa, np. w drugiej części przepisu art. 96 ust. 6 pkt $3^{37}$ poprzez wprowadzenie standardów technicznych instalacji, w których następuje spalanie paliw. Takie rozwiązanie należałoby uznać za w pełni dopuszczalne, zwłaszcza w odniesieniu do nowo powstających lub modernizowanych obiektów budowlanych.

Na marginesie rozważań dotyczących proporcjonalności rozwiązań prawnych, mających na celu ochronę środowiska, warto sięgnąć po kontekst europejski. Jest on szczególnie istotny wobec skargi, jaką Komisja Europejska wniosła 10 grudnia 2015 r. przeciwko Polsce do Trybunału Sprawiedliwości w związku z przekroczeniem obowiązujących standardów cząstek stałych w powietrzu. Oczywiście zarzucane Polsce uchybienia dotyczą lat ubiegłych, jednakże aktualne pozostanie pytanie, w jaki sposób należy stosować przepisy art. 96 u.p.o.ś., aby nie narazić się np. na zarzut naruszenia zasady proporcjonalności - zarówno w ujęciu Konstytucji RP, jak i Traktatu o funkcjonowaniu Unii Europejskiej.

W sporze Komisji z Austrią ${ }^{38}$ państwu temu zarzucono właśnie zastosowanie zbyt restrykcyjnego środka zmierzającego do przestrzegania dopuszczalnych wartości dwutlenku azotu w powietrzu, co stało w sprzeczności z podstawową zasadą traktatową swobodnego przepływu towarów. W stanie faktycznym Austria zamknęła transalpejski korytarz transportowy,

37 Artykuł 96 ustawy w ust. 6 określa obligatoryjne elementy uchwały sejmiku. W punkcie 3 wymienione są „rodzaje lub jakość paliw dopuszczonych do stosowania lub których stosowanie jest zakazane na obszarze, o którym mowa w pkt 1 , lub parametry techniczne lub rozwiązania techniczne lub parametry emisji instalacji, w których następuje spalanie paliw, dopuszczonych do stosowania na tym obszarze".

38 Wyrok TS UE w sprawie C-28/09 z dnia 21 grudnia 2011 r. Komisja przeciwko Republice Austrii, Zb. Orz. TE [2011] I-13525. 
wprowadzając zakaz poruszania się na odcinku autostrady A12 pojazdów ciężarowych o masie powyżej 7,5 tony przewożących towary, proponując alternatywny transport kolejowy. Trybunał przyznał co prawda, że nadrzędne wymogi związane z ochroną środowiska naturalnego mogą uzasadniać krajowe środki potencjalnie utrudniające handel wewnątrzwspólnotowy, muszą one jednak być proporcjonalne do zamierzonego celu, to jest być odpowiednie do zapewnienia realizacji zamierzonego celu i nie wykraczać poza to, co jest konieczne do jego osiągnięcia. Jednocześnie Trybunał uznał, iż Austria naruszyła unijną zasadę proporcjonalności, gdyż założony cel mógł zostać osiągnięty poprzez zastosowanie środka w mniejszym stopniu ograniczającego swobodny przepływ towarów. Zamiast sektorowego zakazu ruchu pojazdów, państwo to mogło wprowadzić np. stałe ograniczenie prędkości do $100 \mathrm{~km} / \mathrm{h}$, co według ekspertów również doprowadziłoby do znacznego zmniejszenia emisji dwutlenku azotu do powietrza.

Z drugiej strony, niechęć do przyjęcia legislacji zbyt daleko ingerującej w prawa i wolności jednostki, która była kontrargumentem dla władz Republiki Włoskiej w sporze z Komisją ${ }^{39}$, nie spotkała się z uznaniem Trybunału. Zarzuty wobec Włoch opierały się na stwierdzeniu, iż te dopuszczając, aby w latach 20062007 w wielu strefach i aglomeracjach stężenie PM10 w otaczającym powietrzu przekraczało wartości dopuszczalne określone w dyrektywie ${ }^{40}$, uchybiły zobowiązaniom państwa członkowskiego. Republika Włoska przyznała, że przestrzeganie wskazanych wartości dopuszczalnych w terminach wyznaczonych w dyrektywie nie było możliwe, ale w tym stanie rzeczy „zapewnienie przestrzegania tych wartości dopuszczalnych wymagałoby zastosowania środków o drastycznych dla gospodarki i społeczeń-

39 Wyrok TS UE w sprawie C-68/11 z dnia 19 grudnia 2012 r. Komisja przeciwko Republice Wtoskiej, ECLI:EU:C:2012:815.

40 Artykuł 5 ust. 1 dyrektywy Rady 1999/30/WE z dnia 22 kwietnia 1999 r. odnoszącej się do wartości dopuszczalnych dla dwutlenku siarki, dwutlenku azotu i tlenków azotu oraz pyłu i ołowiu w otaczającym powietrzu, a w chwili orzekania w art. 13 ust. 1 dyrektywy Parlamentu Europejskiego i Rady 2008/50/WE z dnia 21 maja 2008 r. w sprawie jakości powietrza i czystszego powietrza dla Europy. 
stwa skutkach, a także wiązałoby się z naruszeniem podstawowych praw i swobód takich jak swobodny przepływ towarów i osób, prywatna inicjatywa gospodarcza oraz prawo obywateli do korzystania z usług użyteczności publicznej”. W odpowiedzi Komisja podnosiła, iż żadne z państw członkowskich nie wniosło skargi o stwierdzenie nieważności dyrektyw 1999/30 i 2008/50, a Trybunał stwierdził uchybienie, przy czym - jak dodał - bez znaczenia jest to, czy jest ono wynikiem „zamierzonego działania państwa członkowskiego, któremu jest ono przypisywane, jego niedbalstwa czy też trudności technicznych, z którymi państwo to się zmaga". Zatem argument dotyczący ewentualnego naruszenia zasady proporcjonalności, obowiązującej w systemie prawnym danego państwa członkowskiego, nie spotkał się z uznaniem Trybunału.

\section{PODSUMOWANIE}

W świetle powyższych rozważań należy stwierdzić, że dokonana nowelizacja nie wyeliminowała wątpliwości wokół miejsca, jakie art. 96 zajmuje w systemie ochrony jakości powietrza, a wręcz je wzmogła. Obserwuje się bowiem rozbieżność pomiędzy literą prawa, która nadaje omawianemu przepisowi funkcję subsydiarną, a praktyką organów samorządowych, które chcą go wykorzystywać niemal jako podstawowy oręż w walce z zanieczyszczeniem powietrza, w szczególności ze zjawiskiem tzw. smogu.

Mimo dokonanej nowelizacji, również z punktu widzenia zgodności z konstytucyjną zasadą proporcjonalności, z dużą dozą ostrożności należy podchodzić do stosowania art. 96 u.p.o.ś. Akty prawa miejscowego stanowione na tej podstawie powinny być przyjmowane dopiero po wyczerpaniu innych, mniej restrykcyjnych środków prawnych, a jeśli już zastosowano art. 96 u.p.o.ś., to uchwała sejmiku powinna zawierać rozwiązania jak najmniej dolegliwe z punktu widzenia ochrony praw i wolności jednostki, np. swobody działalności gospodarczej czy prawa własności. W przeciwnym przypadku zbyt daleko idące przy- 
kłady stosowania art. 96 będą narażone na zarzut niezgodności $\mathrm{z}$ art. 31 ust. 3 Konstytucji.

De lege ferenda należałoby zastanowić się nad uchyleniem art. 96 u.p.o.ś. jako samodzielnej jednostki redakcyjnej i ewentualnie umieszczeniem części jego dyspozycji wśród fakultatywnych elementów programów uchwalanych na podstawie art. 84 w związku z art. 91 ust. 3 u.p.o.ś., gdyż zapewniłoby to większą spójność systemu ochrony powietrza. Natomiast w kontekście doraźnego zwalczania tzw. sytuacji smogowych, ustawodawca powinien dokonać zmian w celu wyeliminowania wątpliwości wokół wiążącego charakteru planów krótkoterminowych, co w praktyce legislacyjnej organów samorządowych mogłoby się przełożyć na bardziej skuteczne ich stosowanie.

\section{BIBLIOGRAFIA}

Barczak A., Zadania samorzadu terytorialnego $w$ zakresie ochrony środowiska, Warszawa 2006.

Bosek L., Wild M., Kontrola konstytucyjności prawa. Zagadnienia ustrojowe, procesowe i materialnoprawne, Warszawa 2011.

Bukowski Z., Czech E.K., Karpus K., Rakoczy B., Prawo ochrony środowiska. Komentarz, Warszawa 2013.

Dubowska A., Plan działań krótkoterminowych jako prawny instrument ochrony powietrza, „Przegląd Prawa Ochrony Środowiska” 2015, nr 2.

Górski M., Nowe regulacje prawne w zakresie ochrony jakości powietrza - monitoring i przywracanie wymaganego stanu jakości powietrza, „Acta Iuris Stetinensis 5. Zeszyty Naukowe Uniwersytetu Szczecińskiego" 2014, nr 823.

Górski M., Pchałek M., Radecki W., Jerzmański J., Bar M., Urban S., Jendrośka J., Prawo ochrony środowiska. Komentarz, Warszawa 2014.

Izdebski H., Samorząd terytorialny. Podstawy ustroju i działalności, Warszawa 2014.

Lipiński A., Prawne podstawy ochrony środowiska, Warszawa 2007.

Możdżyń O., Lepsza jakość powietrza i ochrona przed hałasem - planowane zmiany $w$ art. 96 Prawa ochrony środowiska, „Prawo i Śro3/2016 dowisko" 2015, nr 2. 
Rakoczy B., Ograniczenie praw i wolności jednostki ze względu na ochronę środowiska w Konstytucji Rzeczypospolitej Polskiej, Toruń 2006.

Szpor A., Państwo a subsydiarność jako zasada prawa $w$ UE $i w$ Polsce, „Samorząd Terytorialny” 2001, nr 1-2.

Wojtyczek K., Granice ingerencji ustawodawczej $w$ sferę praw człowieka w Konstytucji RP, Kraków 1999.

Kontakt e-mail:

mgmalecka@hotmail.com 